\title{
What to Accommodate to Develop Students' Academic Writing? Need Analysis for a Research-Based Textbook Development
}

\author{
Rizka Safriyani, English Language Education Department, Teacher and Training Faculty, UIN \\ Sunan Ampel, Surabaya, Indonesia \\ Rakhmawati, English Language Education Department, Teacher and Training Faculty, UIN \\ Sunan Ampel, Surabaya, Indonesia \\ Lisanul Uswah Sadieda, English Language Education Department, Teacher and Training \\ Faculty, UIN Sunan Ampel, Surabaya, Indonesia
}

\begin{abstract}
The development of research-based learning proliferates throughout the world, and it depicts the growth of an academic article's publication globally. To strengthen the paper's quality, particularly in Indonesia, the students need a guideline on writing an academic article. This qualitative and quantitative research would portray the needs analysis in developing a research-based textbook in academic writing. Fifty students and thirty lecturers were involved in the interview, documentation, and survey. The result shows that the skills needed to accommodate are referencing skills, writing the research's significance, and writing the conclusion. This study also suggested nine units of an Academic Writing Textbook needed by the students to produce a good article, namely Introduction to Academic Article Writing, Strategies in avoiding plagiarism, Writing an introduction, writing a literature review, writing a research method, Presenting Findings and Discussion, Writing a conclusion, Tips on Referencing, choosing the title, and writing an abstract. These findings strengthen the previous studies, which states that writing an academic article is challenging, particularly in the English Language Teaching context.
\end{abstract}

Keywords: Academic writing article, Research-based learning, Need analysis

\section{INTRODUCTION}

Research-based learning is an important method to develop students' social character, critical thinking, and problem-solving skills. Research in English Language Teaching promotes students' active learning and experiential learning for the students. Moreover, Research-based learning requires students to do research and writes a research report. As a result, students can produce good Academic Writing. However, a limited number of resources can be used as a guideline to conduct Research-based learning in English Language Teaching. Most of Research Methodology textbook do not use the example from English Language Teaching topics. Students get difficulties in finding an excellent example of a research report because they rarely read academic articles.

To accommodate the problems, the teacher needs to develop a research-based textbook. The teacher does need analysis to get accurate information about students' needs, lack, and wants. Darici (2016) stated that the first step to developing the course material is by need analysis. It is an excellent way to identify teaching, learning, and developing the course material. Need analysis is an essential step in the learning process because it is a fundamental and substantial step to design the material, teaching strategies,

86 | IJET| Volume. 10, Issue 1. July 2021 Copyright 2021 Rizka Safriyani, Rakhmawati, and Lisanul Uswah Sadieda are licensed under Creative Commons Atrribution- ShareAlike 4.0 International License. 
media, and evaluation. The primary purpose of need analysis is to identify knowledge and skills mastered and what they want to study. According to Hutchinsons and Water (1987), need consists of two aspects, target need and learning needs. Target need is a goal of the study, and learning need is what the students do to study. Target need covers necessities, lack, and wants.

Students' weaknesses, the language will be mastered, and what the students will be studied are all the students' necessities. The most effective methods require comparing what has been mastered with what still needs to be mastered. Nation and Macalister (2010) explained that if a lecturer conducts need analysis, she will get accurate information about what they want to reach the goal and what they will do in the teachinglearning process. Abderrouf (2016) said that grammar that includes various rules such as tenses, prepositions, word classes, and syntax are the main problems faced by foreign language learners. Here, besides the science of writing scientific articles, grammar is commonly used as one of the quality parameters in assessing academic articles. Ekasari (2020) also found the same information that the challenges are faced mainly by the students in writing English academic papers are the grammatical aspects and the difficulties in developing coherent, cohesive English academic papers to make them understandable. Hartwell (1985) cites various studies concluding that formal grammar teaching does not improve students' grammar mastery. Thus, students should read scientific articles more often in large quantities to get input and exposure to the language commonly used in writing scientific articles. It can be inferred that grammar is one of the critical issues in writing articles.

In the teaching-learning process, course material is essential because it implements and interprets the curriculum to help students achieve basic competence. It has a strategic function in the teaching-learning process, which helps lectures and students in learning activities. Moreover, the course material has a substitute function for lectures, and it supports individual learning. Hamalik (2008) stated many steps to select course material if the material was available and published in society. The steps cover analysis of curriculum goal, scope, concept, principle, aspect of analysis, selecting and designing material based on the analysis result, and evaluate the comparability with the material with the goal of learning.

An excellent title for a research paper could introduce the research work to the full degree, but concisely, on its own (Bavdekar,2016). Moreover, it does not write abbreviations, jargon, number even though it implies keywords. Swales, John, and Christine (2012) and Klimova (2013) mentioned that abstract categories could be divided into indicative and informative abstracts. The indicative abstract explains all the processes have done without writing the result of the research findings. So, the informative abstract writes it and shows it to the reader. Swales (2004) stated that the introduction of the research covers problems, research gaps, and research questions. Arikunto (2002) wrote a research methodology to describe data collection and data analysis. Research methodology has the role of finding the data to answer research questions. Wahidmurni (2017) explained in finding and discussion. The process shows data display and discussion. Suppose the qualitative design will present the quotation from an interview, observation, document, and the result of the questionnaires' analysis.

87 | IJET| Volume. 10, Issue 1. July 2021 
In quantitative research, the test and questionnaire results show detail, even the validity of the test instrument informs early. So, the conclusion is a summary of the research finding achievement.

Research-based textbook creation provides resources based on the research findings of a research project to assist students with a recent global academic article writing trend in English Language Teaching. A research-based textbook promotes learning sources as course content while also providing structured concepts and information on how to write an academic article. Doing research is not a simple task for a novice researcher. They can have much trouble arranging the piece or carrying out the study. Many research technique textbooks focus on research in the social sciences, and only a few textbooks provide an accurate and specific example for English Language Teaching. Therefore, the need to have a Research-based textbook based on the students' is essential.

Some studies discuss the research on need analysis and common problems in Academic Writing. Tjalla (2016) mentioned that the average university student has difficulties writing English academic articles because of their low English skill. The result of the need analysis stated the vocabularies, grammar, strategies to write an English academic article, and skill are four competencies that students must master. Indah (2016) also notes that she identified inappropriateness types of in-text citation in writing authors' names, the employment of speaker tags, the punctuation, and the mechanic of writing in a paragraph. She said that some students' challenges in writing references include the sorts of reference list contained the characteristics of writing reference unalphabetically and did not employ indentation. The following study by Ahmed (2010) claimed that Some Egyptian student teachers of English experienced some coherence problems in their academic writing. The problems covered the difficulties in writing the introduction, the thesis statement, the topic statement, and the conclusion. Another study by Dehnad et al. (2010), Cosletidou (2010), Benavent and Sonsoles Sánchez- Reyes(2015), Aliakbari and Boghayeri(2014), and Sucipto (2010) have discussed the role of need analysis in syllabus development. Those previous studies do not use research-based learning as the teaching method. Moreover, few studies discuss research-based textbook development. Since this study involves research-based learning, this study's result would contribute to academic writing development in English Language Teaching

\section{METHOD}

The students who participated were between the ages of 18 and 22 years. Each student of the English Language Education Department had an equal chance of being selected. Fifty students and thirty lecturers were involved in the interview, documentation, and survey. A letter of information containing details about the study and visit dates was given to the participants before the study. Next, the participants filled the consent form. The sample size was chosen based on the Cohens' formula. The lecturers who participated were between the ages of 25 and 50 years. This research design was qualitative and quantitative because it captured the students' course material needed and generalizes the course unit material needed.

88 | IJET | Volume. 10, Issue 1. July 2021

Copyright 2021 Rizka Safriyani, Rakhmawati, and Lisanul Uswah Sadieda are licensed under Creative Commons Atrribution- ShareAlike 4.0 International License. 
The instruments were questionnaires, interview guides, and rubrics for the document analysis. The questionnaires consist of 24 open questions and two self-rated questions with five Likert scales. The first self-rated questions describe the importance of fifteen topics in academic article writing, and the second self-rated questions describe the students' mastery level towards the fifteen topics in academic article writing. The data were collected four times from August to September 2019. The researcher used the interview guide within the interview and Focus Group Discussion (FGD). The reliability of the questionnaire was $\mathrm{r}=0.7, \mathrm{p}<0.001$.

The researcher used document analysis, questionnaires, and focus group discussion on collecting data about students' needs, lack, and wants. The document analysis, interview, and FGD were performed during September 2019. Two lecturers assessed fifty documents of the students' research reports by using the article review form. The questionnaire results will be triangulated through interviews with several students as samples and lecturers in charge of courses and the Head of the English Education Study Program. Data on skills that students have not mastered are collected through an assessment of English-language paper products written by students. The process of data collection for the assessment of the ability to write academic articles is assessed based on nine main criteria adapted from the guidelines for assessing journal articles in the English Education Study Program (IJET), which consist of the ability to write abstracts, the ability to develop backgrounds, the ability to formulate problem formulations, the ability to formulate research benefits, the ability to write literature reviews, the ability to formulate research methodologies, the ability to formulate research results, the ability to formulate conclusions and the ability to compile references and citation software. As a guide for assessing the paper, the assessment of each aspect will be arranged based on the main idea, grammar, reference writing, and plagiarism level. For each criterion, the maximum score achieved is 5 with a description of the main idea being clear, coherent, using the correct and accurate APA format and accompanied by a powerful synthesis, low plagiarism (similarity index below 15\%), and no grammatical errors.

A score of 4 can be obtained if the main idea is clear, coherent but accompanied by minimal synthesis and moderate plagiarism (15-25\% similarity index), and there are only a few grammatical errors in certain parts. A score of 3 can be obtained if the main idea is clear, coherent but not accompanied by analysis and moderate plagiarism (similarity index 15-25\%), there are some grammatical errors at the beginning and end of the sentence and using the correct APA format. A score of 2 can be obtained if the main idea is clear but not coherent, some parts have high plagiarism (similarity index 25-50\%), many grammatical and spelling errors at the beginning of the sentence and the end of the sentence, using the wrong APA format in some cases. A score of 1 can be obtained if the main idea is not clear and not coherent and even plagiarism is very high (similarity index above 50\%), many grammatical and spelling errors throughout the section, and uses the wrong APA format. With the assessment instructions above, the maximum score that students can achieve is 45 , while the lowest score that students can

89 | IJET| Volume. 10, Issue 1. July 2021 Copyright 2021 Rizka Safriyani, Rakhmawati, and Lisanul Uswah Sadieda are licensed under Creative Commons Atrribution- ShareAlike 4.0 International License. 
achieve is 9. At the data collection stage, a Focus Group Discussion (FGD) was also conducted, which involved lecturers in the Academic Article Writing course, lecturers in cognate courses, and the Chair and Secretary of the UINSA English Language Education Department. This FGD obtained data on what final skills students must master in Academic Article Writing and indicators of the achievement of these final abilities. In addition, the FGD will also qualitatively provide information about Academic Article Writing skills that students have not mastered. These results would later be triangulated from the results of student paper assessments.

The data in this study are (1) data on the wants (wants) of students, lecturers, and English Education Study Program regarding the need for research-based teaching materials for the Academic Article Writing course, (2) data on abilities that have not been mastered by students (lacks) in writing articles. Academic papers in English and (3) data on the need for research-based teaching materials development for Academic Article Writing courses. Groups of data on wants (wants) were obtained through questionnaires, interviews, and FGDs; data on abilities that had not been mastered by students (lacks) were obtained through paper assessments and data on development needs. There were several procedures applied in data analysis. The first part of the data analysis would transcript the interview result, reduce the irrelevant data, code the data, and display the data about students' needs, lack, and wants. Data reduction is defined as the process of selecting, focusing on simplification, abstraction, and transformation of rough data that emerges from written notes in the field. In addition to using data reduction, researchers also use triangulation techniques to check the validity of the data. In this study, the data that is reduced is not relevant to the research question. This irrelevant data comes from research subjects during interviews or filling out questionnaires. Triangulation was carried out on the sources. Triangulation with sources means comparing and doublechecking the degree of trustworthiness of information obtained through different times and tools in qualitative research. As for achieving that trust, the following steps were taken: 1. Comparing the observational data with interview data, 2. comparing what people said in public with what was said in private. 3. Compare what people say about the research situation with what they say over time. 4. Comparing one's situation and perspective with various opinions and views of people from various classes. 5 . Comparing the results of interviews with the contents of a related document.

The collected quantitative data is processed in three steps: editing, coding, and tabulation. Editing is the process of re-examining the data that has been filled in or answered by the respondent. At this stage, the researcher re-examined the questionnaire that 50 respondents had filled out. The next step is coding respondents' answers classified according to the type of question by marking each data that belongs to the same category. The last step is tabulation which is done to group answers based on the same category into tabular form. In the questionnaire, two questions show attitudes and are measured by a Likert scale. The Likert scale contains frequent questions to indicate a person's attitude towards the question. There were five possible responses to the

90 | IJET| Volume. 10, Issue 1. July 2021 Copyright 2021 Rizka Safriyani, Rakhmawati, and Lisanul Uswah Sadieda are licensed under Creative Commons Atrribution- ShareAlike 4.0 International License. 
question of what material had been mastered: strongly agree, agree on a value of 5, agree on a value of 4 , neutral on a value of 3 , disagree with a value of 2 , and severely disagree a value of 1 . The second part of the data analysis would be scoring the students' writing by editing, coding, and tabulation. The paper and self-assessment results were analyzed by the descriptive statistic of SPSS 25 software and Lisrel 8.7 to investigate the mean score of the student's ability to write an academic article. This statistical process was also done to investigate which factor mainly contributes to their academic writing score.

\section{RESULTS AND DISCUSSION}

Self-rated questions were distributed to the students and lecturers to portray their needs, lack, and wants. The self-rated questions would grade students' writing the abstract, the background of the research, research problems, the significance of the research, references, research methodology, conclusion, and the ability to write references and use citation software. The result of the analysis can be shown in table 1 below:

\section{Table 1}

\section{Students' ability in writing an Academic Article}

\begin{tabular}{|c|c|c|c|c|c|c|c|c|c|c|c|}
\hline & & $\begin{array}{l}\text { Abstr } \\
\text { act }\end{array}$ & $\begin{array}{c}\text { Back } \\
\text { grou } \\
\text { nd }\end{array}$ & $\begin{array}{c}\text { Res } \\
\text { earc } \\
\text { h } \\
\text { pro } \\
\text { ble } \\
\text { m }\end{array}$ & $\begin{array}{l}\text { Signific } \\
\text { ance of } \\
\text { study }\end{array}$ & $\begin{array}{c}\text { Review } \\
\text { of } \\
\text { related } \\
\text { literatur } \\
\text { e }\end{array}$ & $\begin{array}{c}\text { Resear } \\
\text { ch } \\
\text { metho } \\
\text { dology }\end{array}$ & $\begin{array}{c}\text { Researc } \\
\text { h } \\
\text { Finding }\end{array}$ & $\begin{array}{l}\text { Concl } \\
\text { usion }\end{array}$ & $\begin{array}{l}\text { Refer } \\
\text { ences }\end{array}$ & $\begin{array}{l}\text { Total } \\
\text { of } \\
\text { mark }\end{array}$ \\
\hline $\mathrm{N}$ & Valid & 50 & 50 & 50 & 50 & 50 & 50 & 50 & 50 & 50 & 50 \\
\hline & Missing & 0 & 0 & 0 & 0 & 0 & 0 & 0 & 0 & 0 & 0 \\
\hline $\mathrm{Me}$ & & 3.48 & 3.18 & 3.48 & 2.28 & 3.38 & 3.54 & 3.52 & 2.58 & 2.68 & 62.30 \\
\hline & Error of & .167 & .089 & .071 & .172 & .110 & .141 & .071 & .131 & .147 & 1.152 \\
\hline & lian & 4.00 & 3.00 & 3.00 & 2.00 & 4.00 & 3.00 & 4.00 & 3.00 & 3.00 & 63.00 \\
\hline $\mathrm{Mc}$ & & 2 & 3 & 3 & 1 & 4 & 3 & 4 & 3 & 3 & 64 \\
\hline Stc & iation & 1.182 & .629 & .505 & 1.213 & .780 & .994 & .505 & .928 & 1.039 & 8.147 \\
\hline
\end{tabular}

91 | IJET| Volume. 10, Issue 1. July 2021 Copyright 2021 Rizka Safriyani, Rakhmawati, and Lisanul Uswah Sadieda are licensed under Creative Commons Atrribution- ShareAlike 4.0 International License. 


\begin{tabular}{|l|r|r|r|r|r|r|r|r|r|r|}
\hline Variance & 1.398 & .396 & .255 & 1.471 & .608 & .988 & .255 & .861 & 1.079 & 66.378 \\
\hline Range & 3 & 2 & 1 & 3 & 2 & 3 & 1 & 3 & 3 & 26 \\
\hline Minimum & 2 & 2 & 3 & 1 & 2 & 2 & 3 & 1 & 1 & 47 \\
\hline Maximum & 5 & 4 & 4 & 4 & 4 & 5 & 4 & 4 & 4 & 73 \\
\hline
\end{tabular}

Based on table 1 above, it can be concluded that the average total mark is 62.30 . In other words, their mastery level is average. Table 1 shows that students' ability to write references, conclusions and the writing significance of the research were below the standard. These three skills are the skills that are most needed to be accommodated. Considering the students' wants, students believe that all of the skills in academic writing are important. However, comparing the need, the lack, and they want, students need to develop their skills in writing a conclusion since they usually copy the document. The forum group discussion resulted in a similar opinion about course material needed from students' and lectures' perspectives. The similarity is illustrated in diagram 1 below:

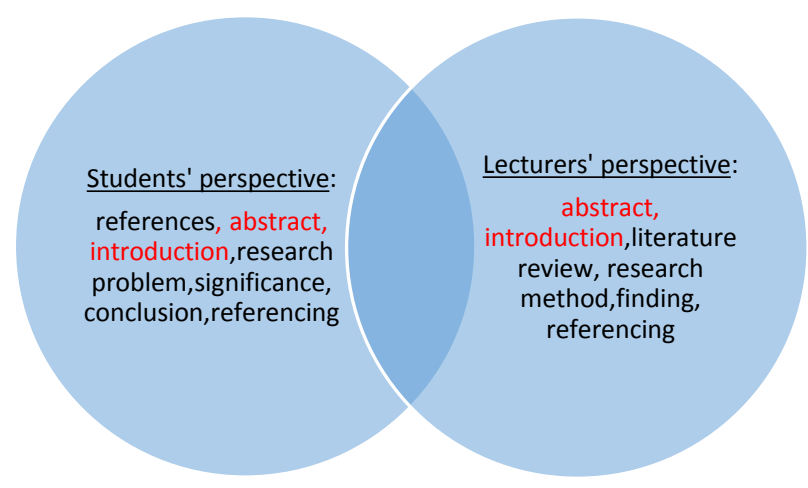

Diagram 1

\section{Students' need from the students' point of view and lecturers' point of view}

From diagram 1, it can be concluded that both students and lecturers believe that abstract and introduction were the two essential elements that needed to be accommodated. Moreover, the lecturers recommended the unit course of the material in table 2 below :

Table 2

\section{Outline of the textbook}

\begin{tabular}{|c|l|l|}
\hline Unit & \multicolumn{1}{|c|}{ Material } & Meeting \\
\hline Unit 1 & Introduction to an academic journal & 1 \\
\hline Unit 2 & Strategies to avoid plagiarism & 2 \\
\hline Unit 3 & Writing background of the study & 2 \\
\hline
\end{tabular}

92 | IJET| Volume. 10, Issue 1. July 2021 Copyright 2021 Rizka Safriyani, Rakhmawati, and Lisanul Uswah Sadieda are licensed under Creative Commons Atrribution- ShareAlike 4.0 International License. 


\begin{tabular}{|l|l|l|}
\hline Unit 4 & Writing review of related literature & 1 \\
\hline Unit 5 & Writing research methodology & 1 \\
\hline Unit 6 & Writing finding and discussion of the research & 2 \\
\hline Unit 7 & Writing conclusion & 1 \\
\hline Unit 8 & Writing references & 1 \\
\hline Unit 9 & Writing the research title & 1 \\
\hline $\begin{array}{l}\text { Unit } \\
10\end{array}$ & Writing an abstract & 2 \\
\hline
\end{tabular}


These units could help students to produce good article writing. These recommendations were presented because students confirm that all aspects were important. Furthermore, the lecturer belief that most students did not know about academic journals and academic articles in Indonesia. Therefore, a specific unit introduces the students to the journal to have background knowledge about academic writing. Another unit promoted in this textbook is the second unit about strategies for avoiding plagiarism. Since plagiarism was a big issue, students need to know the strategies to avoid plagiarism when writing academic writing.

This study discusses what should be accommodated to develop students' academic writing. The previous findings show that students' ability is at an average level. The students' grammar mastery possibly becomes the cause of the average ability in writing academic articles. Almost all of the examples presented in the discussion section contained grammatical errors. Some students omit the function words. Omission of the article, incorrect prepositions (in and on) could be easily found in the students' article. This omission is corroborated with the finding of Abderrouf's (2016) study, which states that grammatical errors are one of the significant issues for a foreign language learner. The interference of the native language may influence students' writing. Many students use direct translation from Indonesian to English so that grammatical errors occur. Previous reports have also shown that grammatical aspects are the most challenging aspect of academic writing (Ekasari,2020). It means that grammar would influence the students' ability to write academic articles. They will not produce a magnificent introductory paragraph, literature review, or a good discussion if they do not master grammar.

The finding has revealed that writing abstract and introduction were the two essential elements that needed to be accommodated. Both aspects were also found in the interview results.

"Many students omit the introductory sentences in their abstract. Most of them write the purpose of the research as the first sentence in their abstract. They also got confused with the tenses used in the abstract. In writing an introduction, students also skip some rhetorical moves. There were only a few students who introduced the research parameters on their introduction." (L2)

Both lecturer and students believe that introduction and abstract are basic units accommodated in the textbook. People usually read the abstract first before diving into the rest of the article. As a result, it should be written with extreme caution. It could be the most crucial aspect of one's writing. Previous reports have also shown that articles, agreement in subject and predicate, tenses, existential-locative phrases with prepositions, spelling, proper register, extended sentences, word repetition, punctuation, and capital letters are among the other errors (Klimova, 2013). Other reports have also shown that many students did not introduce the research parameters in writing an introduction, indicate a possible extension in previous research, and justify the research (Stapa et al., 2014). However, the student's draft showed a different result. Based on their work, the finding shows that students' ability to write references, conclusions and the writing significance of the research were below the standard. Students do not always pay attention to what aspects must be written when writing. If students use the word bibliography in the bibliography section, all of these sources are references that may not be directly quoted. However, if students use the phrase references, the whole list of sources on that page must be cited in the research master document scientific paper. When quoting a

94 | IJET| Volume. 10, Issue 1. July 2021

Copyright 2021 Rizka Safriyani, Rakhmawati, and Lisanul Uswah Sadieda are licensed under Creative Commons Atrribution- ShareAlike 4.0 International License. 
journal, students sometimes neglected to provide the page number. Based on the document assessment results, compiling references and citation software, concluding and formulating research benefits received the lowest grade. When writing references, students frequently overlook the need for consistency. Some students use the terms bibliography and references interchangeably. This result is in agreement with the findings of a previous study where the inappropriateness types of in-text citation in features of writing authors' name, the employment of speaker tag, the punctuation, and mechanic of writing in a paragraph (Indah, 2016). She said that some students' challenges in writing references include the sorts of reference list contained the characteristics of writing reference unalphabetically and did not employ indentation.

Conclusions should include conclusions regarding the study findings that address the research challenge. As a result, if the number of study problem formulations is presented, the conclusion is easier to comprehend. The research gap identified in the introduction or background must be addressed in conclusion. Frequently, conclusions are accompanied by directions that define the field of future research. The research results will be less precise if the conclusions are unclear. Conclusions will show how the author achieves his study objectives and the outcomes of analyzing the research findings. In this study, many students believed that writing a conclusion is difficult. These findings are supported by the results of Ahmed (2010), who found a similar problem with the student-teacher in Egypt. His study has discovered that some coherence problems covered the difficulties in writing the introduction, the thesis statement, the topic statement and the conclusion. This result indicates that the capacity of students to write coherent writing is equally important in establishing the quality of a reasonable conclusion. Students would most likely compose a more substantial opening and conclusion if they could produce readable content. The document analysis reveals that the conclusion reached does not yet reflect the research's core findings.

In writing the research's significance, students often consider this part of a formal part only written to complement research. The significance of this research is the reason why this research was conducted. The significance of this research is also often associated with the novelty of the research. Marco (2000), in his article entitled The Construction of Novelty in Computer Science papers, states that novelty is essential in research because it makes research worth publishing. The general structure of the formulation of novelty sentences is to compare articles written with previous research. This structure refers to the importance of bringing up the research gap. When students have written research gaps and novelty, the research benefits will be formulated theoretically and practically.

Textbooks and course books are examples of printed materials. Despite their distinct names, they have the same meaning and serve the same purpose. Teachers must determine whether or not to apply the lesson on a given page with their class when they open a page in their textbook. The teacher will wish to utilize the textbook if the language, content, and sequencing are suitable. On the other hand, if the textbook has a flaw, the teacher must determine what to do next. To make a good textbook, a teacher should develop the material based on the result of the need analysis. The finding of this study has shown the result of the need analysis that may be different from their belief. However, all the necessities lack and wants could be corroborated to develop a research-based textbook in academic writing.

Regarding attractiveness, suitability of the content, and level of difficulty, the items are appropriate for students as textbook users. The suggested units are focused on the needs and interests of the students. The subjects and tasks offered in the materials are relevant to the

95 | IJET| Volume. 10, Issue 1. July 2021 Copyright 2021 Rizka Safriyani, Rakhmawati, and Lisanul Uswah Sadieda are licensed under Creative Commons Atrribution- ShareAlike 4.0 International License. 
student's subject knowledge and their daily lives in and out of the classroom. This result is in agreement with the findings of a previous study where the researcher found that the students have good responses to the developed book. They have the motivation to learn English. They are interested in learning English because the book is helpful and offer activities to practice their skill (Pindika, 2019). Therefore, developing a research-based textbook is beneficial not only for the lecturers but also for the students.

\section{CONCLUSION}

This study investigates the needs analysis in developing a research-based textbook in academic writing. Based on the results of interviews and questionnaires, the materials needed in researchbased teaching materials are referencing skills, writing the research's significance, and writing the conclusion. This study also suggested nine units of an Academic Writing Textbook needed by the students to produce a good article, namely Introduction to Academic Article Writing, Strategies in avoiding plagiarism, Writing an introduction, writing a literature review, writing a research method, Presenting Findings and Discussion, Writing a conclusion, Tips on Referencing, choosing the title, and writing an abstract. The part of the material that is most needed in research-based teaching materials in the Academic Article Writing course based on the opinions of lecturers, students, and study program leaders is the abstract and background preparation section. There are certain limitations to this study that should be considered. In this study, the students had different writing interests. Thus, it is suggested that further research examine the development of a research-based textbook for a different type of genre.

\section{REFERENCES}

Abderrouf, Annab. (2016). Investigating EFL students' writing difficulties and common errors in writing. http://univbejaia.dz/dspace/bitstream/handle/123456789/5858/Investigating\%20EFL\%20stu dents $\% 27 \% 20$ writing $\% 20$ difficulties $\% 20$ and $\% 20$ common $\% 20$ errors $\% 20 \mathrm{in} \% 20 \mathrm{w}$ riting.pdf? sequence $=1 \&$ isAllowed $=y$

Ahmed, A. H. (2010). Students' Problems with Cohesion and Coherence in EFL Essay Writing in Egypt: Different Perspectives. Literacy Information and Computer Education Journal (LICEJ), 1, 214-221.

Aliakbari, A. , Boghayeri, M. (2014). A Needs Analysis Approach to ESP Design in Iranian Context. Procedia - Social and Behavioral Sciences 98,175 - 181

Arikunto, Suharsimi. (2002). Prosedur Penelitian; Suatu Pendekatan Praktek Jakarta: Rineka Cipta

Bavdekar, S. B. (2016). Formulating the right title for a research article. Journal of

96 | IJET| Volume. 10, Issue 1. July 2021

Copyright 2021 Rizka Safriyani, Rakhmawati, and Lisanul Uswah Sadieda are licensed under Creative Commons Atrribution- ShareAlike 4.0 International License. 
Association of Physicians of India, 64(February), 53-56.

Benavent. G.T.A, Sánchez-Reyes, S. (2015). Target situation as a key element for ESP (Law Enforcement) syllabus design. 32nd International Conference of the Spanish Association of Applied Linguistics (AESLA): Language Industries and Social Change. Procedia - Social and Behavioral Sciences 173,143 - 148.

Chostelidou, D. (2010). A Need Analysis Approach to ESP Syllabus Design in Greek Tertiary Education: a Descriptive Account of Students' Needs. Procedia Social and Behavioral Sciences 2, 4507-4512.

Darici A. (2016) The Importance of Needs Analysis in Materials Development. In: Azarnoosh M., Zeraatpishe M., Faravani A., Kargozari H.R. (eds) Issues in Materials Development. Critical New Literacies: The Praxis of English Language Teaching and Learning (PELT). SensePublishers, Rotterdam. https://doi.org/10.1007/978-94-6300-432-9_3.

Dehnad, A., Bagherzadeh, R., Bigdeli, S, Hatami, K., Hosseini, F. (2010). Syllabus revision: a needs analysis Study. Procedia Social and Behavioral Sciences 9 $1307-1312$

Ekasari, Yulita, (2020), Exploring Students' Challenges in Writing English Academic Papers: A Case Study in English Language Education Department of UINSA. Unpublished Thesis. English Language Education Department, Faculty of Tarbiyah and Teacher Training, State Islamic University of Sunan Ampel Surabaya.

Hamalik, O. (2008). Kurikulum dan Pembelajaran. Jakarta: Sinar Grafika.

Hartwell, P. (1985). Grammar, Grammars, and the Teaching of Grammar. In J. Caroll \& E.Wilson, Acts of teaching (pp. 205-207). Englewood, Colo: Teacher Ideas Press.

Hutchinson, T, Waters, A. (1987). English for Specific Purposes. Cambridge: Cambridge University Press.

Indah, Dewi Ratna Intan Permata.(2016). Analysis on the Problems in Writing References Of Students. Unpublished Thesis. University Of Nusantara PGRI Kediri retreieved from http://simki.unpkediri.ac.id/mahasiswa/file_artikel/2016/12.1.01.08.0041.pdf

Klimova, Blanka Frydrychova.(2013). Common Mistakes in Writing Abstracts in English. Procedia - Social and Behavioral Sciences 93 ( 2013 ) 512 - 516

Marco, M. Joze Luzon. (2000). The Construction of Novelty in Computer Science papers. Jurnal Revista Alicantina de Estudios Ingleses 13: 12314.https://core.ac.uk/download/pdf/16358965.pdf

Nation, ISP, Macalister, J. (2010). Language Curriculum Design. NY: Taylor \& Francis.

97 | IJET| Volume. 10, Issue 1. July 2021 Copyright 2021 Rizka Safriyani, Rakhmawati, and Lisanul Uswah Sadieda are licensed under Creative Commons Atrribution- ShareAlike 4.0 International License. 
Stapa, Siti Hamin et.al. (2014). Identifying problems in writing thesis introductions in research methodology class. Procedia - Social and Behavioral Sciences 112 ( 2014 ) $497-502$

Sucipto, Agung. 2010. Developing English I Syllabus For The Islamic Education Department (PAI) Islamic College (STAI) Of Ar Rosyid Surabaya. Thesis. Graduate Program in English Language Education, State University of Malang

Swales, J. (2004). Research Genres: Exploration and applications. Cambridge: Cambridge University Press

Swales, John M, Christine B.Feak. (2012). Academic Writing for Graduate Students. Michigan: University of Michigan

Tjalla, M., Akil, M., Hamra, A., Haryanto. (2017). The Analysis of EFL Students' Needs for Writing Materials Development. International Journal of Science and Research (IJSR) Volume 6 Issue 8, Agustus.

Wahidmurni.(2017). Memaparkan Data Dan Temuan Penelitian.Malang:UIN Maulana Malik Ibrahim Malang. http://repository.uin-malang.ac.id/1939/1/1939.pdf retrieved on 1 Oktober 2019 